\title{
INVESTIGATION ON ELECTRONIC AND THERMOELECTRIC PROPERTIES OF (P, As, Sb) DOPED ZrCoBi
}

\author{
(D)Djelti Radouan ${ }^{\mathrm{a}, *}$, (D) Besbes Anissa ${ }^{\mathrm{b}}$, (D) Bestani Benaouda ${ }^{\mathrm{b}}$ \\ ${ }^{a}$ Technology and Solids Properties Laboratory, University of Mostaganem (UMAB) - Algeria \\ ${ }^{b}$ SEA2M Laboratory, University of Mostaganem (UMAB) - Algeria \\ *Corresponding Author:djeltired@yahoo.fr, Radouane.djelti@univ-mosta.dz \\ Received October 9, 2020; revised December 3, 2020; acceped December 4, 2020
}

\begin{abstract}
Since the last decade, the half-Heusler (HH) compounds have taken an important place in the field of the condensed matter physics research. The multiplicity of substitutions of transition elements at the crystallographic sites X, Y and (III-V) elements at the Z sites, gives to the $\mathrm{HH}$ alloys a multitudes of remarkable properties. In the present study, we examined the structural, electronic and thermoelectric properties of $\mathrm{ZrCoBi}_{0.75} \mathrm{Z}_{0.25}(\mathrm{Z}=\mathrm{P}$, As, Sb) using density functional theory (DFT). The computations have been done parallel to the full potential linearized augmented plane wave (FP-LAPW) method as implemented in the WIEN2k code. The thermoelectrically properties were predicted via the semi-classical Boltzmann transport theory, as performed in Boltztrap code. The obtained results for the band structure and densities of states confirm the semiconductor (SC) nature of the three compounds with an indirect band gap, which is around $1 \mathrm{eV}$. The main thermoelectric parameters such as Seebeck coefficient, thermal conductivity, electrical conductivity and figure of merit were estimated for temperatures ranging from zero to $1200 \mathrm{~K}$. The positive values of Seebeck coefficient (S) confirm that the $\mathrm{ZrCoBi}_{0.75} \mathrm{Z}_{0.25}(\mathrm{x}=0$ and 0.25$)$ are a p-type $\mathrm{SC}$. At the ambient temperature, $\mathrm{ZrCoBi}_{0.75} \mathrm{P}_{0.25}$ exhibit the large $\mathrm{S}$ value of $289 \mu \mathrm{V} / \mathrm{K}$, which constitutes an improvement of $22 \%$ than the undoped $\mathrm{ZrCoBi}$, and show also a reduction of $54 \%$ in thermal conductivity $(\kappa / \tau)$. The undoped $\mathrm{ZrCoBi}$ has the lowest $\mathrm{ZT}$ value at all temperatures and by substituting bismuth atom by one of the sp elements ( $\mathrm{P}, \mathrm{As}, \mathrm{Sb})$, a simultaneous improvement in $\kappa / \tau$ and $\mathrm{S}$ have led to maximum figure of merit (ZT) values of about 0.84 obtained at $1200 \mathrm{~K}$ for the three-doped compounds.
\end{abstract}

KEYWORDS: First-principle, GGA, Doped-semiconductor, Seebeck coefficient, figure of merit

The half-Heusler $(\mathrm{HH})$ semiconductors have attracted substantial interest of researchers, they are considered as alternative and green energy sources because they have the capacity to transform waste heat into electric energy. A significant change in their thermoelectric properties can be observed by the incorporation of a dopant at various concentration rates. Many researches on the thermoelectric properties of $\mathrm{HH}$ compounds show moderately high ZT of $\approx 1.0$ in the mid to high temperature ranges $(700-1000 \mathrm{~K})$ [1] which makes them as potential candidates for high efficiency power generation. Recently, several experimental [2-4] and theoretical [5-7] studies have been focused on the doped HH alloys, these last can be utilized in a broad temperature region and a good part of their raw materials are nontoxic, abundant and cheap [8-11]. The single doping remains one of the effective process, which adjust the electrical power factor and reduce the thermal conductivity [12]. C.C. Hsu et al., [13] have studied the $\mathrm{ZrFe}_{\mathrm{x}} \mathrm{Co}_{1-\mathrm{x}} \mathrm{Sb} \mathrm{HH}$ and they show that for $\mathrm{x}=0.2$, the maximum $\mathrm{ZT}$ value of 0.036 was obtained at $900 \mathrm{~K}$, they attribute this to reduction of thermal conductivity because the point defects, mass alterations and strain field effects induced by doping vigorously scatter the thermal phonons. Y.Lei et al. [14] have explored the impact of Sb doping on thermoelectric properties of TiNiSn HH, they noted that the ZT value is moderately improved from 0.30 for undoped alloy to 0.44 for a dopant concentration of 3\%. R. Akram et al [15] find that the incorporation of $1.5 \%$ of $\mathrm{Sb}$ in $\mathrm{Hf}_{0.25} \mathrm{Zr}_{0.75} \mathrm{NiSn} \mathrm{HH}$ enhanced the electrical properties by increasing the carrier concentration and reducing the thermal conductivity. A maximal ZT value of 0.83 was achieved at $923 \mathrm{~K}$, which constitute $67 \%$ of improvement compared to the undoped sample value. In another work [16], the $\mathrm{La}_{\mathrm{x}} \mathrm{Zr}_{1-\mathrm{x}} \mathrm{NiSn}$ compounds, was synthetized by induction melting combined with plasma-activated sintering, the x-ray diffraction confirms that for all $\mathrm{x}$-concentration of La, the structures remain cubic with space group F-43m. A particular drop in thermal conductivity was found following doping by La, thus leading to ZT of 0.53 at $923 \mathrm{~K}$, which represent an enhancement of about $37 \%$ compared to the pristine sample. In the present work, we studied the electronic and thermoelectric properties of sp elements ( $\mathrm{P}, \mathrm{As}, \mathrm{Sb}$ )-doped $\mathrm{ZrCoBi}$ half-Heusler alloy. A brief commentary on the band structure and densities of states are given. A particular emphasis was placed on the thermoelectric properties investigated by the semi-classical Boltzmann theory.

\section{COMPUTATIONAL METHOD}

The computations are performed by the full potential linearized augmented plane wave (FP-LAPW) method [17-18] based on DFT [19] as implemented in Wien2K package [20]. The generalized gradient approximation (GGA) [21] is employed for the exchange-correlation potential. The muffin-tin sphere radii RMT were chosen as equal to $1.85,2.1$ and $2.5 \mathrm{a} . \mathrm{u}$ for the $\mathrm{Zr}$, Co and $(\mathrm{Bi} / \mathrm{P}, \mathrm{As}, \mathrm{Sb})$ atoms respectively. For convergence, the energy cut off $=-6.0 \mathrm{Ry}$, $\operatorname{Gmax}=12, \operatorname{lmax}=10$ and $\mathrm{RMT}^{*} \mathrm{~K}_{\max }=7$ are used. The $22 \times 22 \times 22 \mathrm{k}$-point mesh is used for electronic properties calculation. The self-consistency is achieved up to $0.0001 \mathrm{Ry}$. The space group of cubic $\mathrm{ZrCoBi}$ is 216 (F-43m). According to reference [22], the compound is stable in paramagnetic phase and the atomic coordinates are $(0,0,0),(0.25$, $0.25,0.25)$ and $(0.5,0.5,0.5)$ for $\mathrm{Zr}$, Co and Bi respectively. With the aim of creating $25 \%$ concentration of doping in 
ZrCoBi lattice, the supercell $1 \times 1 \times 1$ containing twelve atoms is constructed. The dopant elements (Phosphor, Arsenic and Antimony) was substituted at the Bismuth site. The space group number of this generated super cell is $215(\mathrm{P}-43 \mathrm{~m}) \mathrm{which}$ contains $4 \mathrm{Zr}$ atoms, $4 \mathrm{Co}$ atoms and $4 \mathrm{Bi}$ atoms. For the four $\mathrm{Bi}$ atom, the one who is situated at the $(0,0,0)$ position was replaced with $(\mathrm{P} / \mathrm{As} / \mathrm{Sb})$ atom without disturbing the other eleven atoms $(4 \mathrm{Zr}, 4 \mathrm{Co}$ and $3 \mathrm{Bi})$ in the supercell. The semi-classical Boltzmann approach [23] as given in the BoltzTraP code associated to a fine grid mesh of $(46 \times 46 \times 46)$ were employed to investigate the thermoelectric response of compounds doped and undoped.

\section{RESULTS AND DISCUSSION \\ Structural and electronic properties}

The crystal structure of the perfect $\mathrm{ZrCoBi} \mathrm{HH}$ and the doped $\mathrm{ZrCoBi}_{0.75} \mathrm{Z}_{0.25}(\mathrm{Z}=\mathrm{P}, \mathrm{As}, \mathrm{Sb})$ are plotted by the CrystalMaker 2.7 software [24]. The undoped structure of $\mathrm{ZrCoBi}$ (Fig.1a) is formed by three interpenetrating fcc sublattices, which are occupied by $\mathrm{Zr}$, Co and $\mathrm{Bi}$ elements. Its lattice constant obtained from optimization is in good agreement with the value of $6.22 \AA$, achieved by G. Surucu [22] using the GGA-PBE.
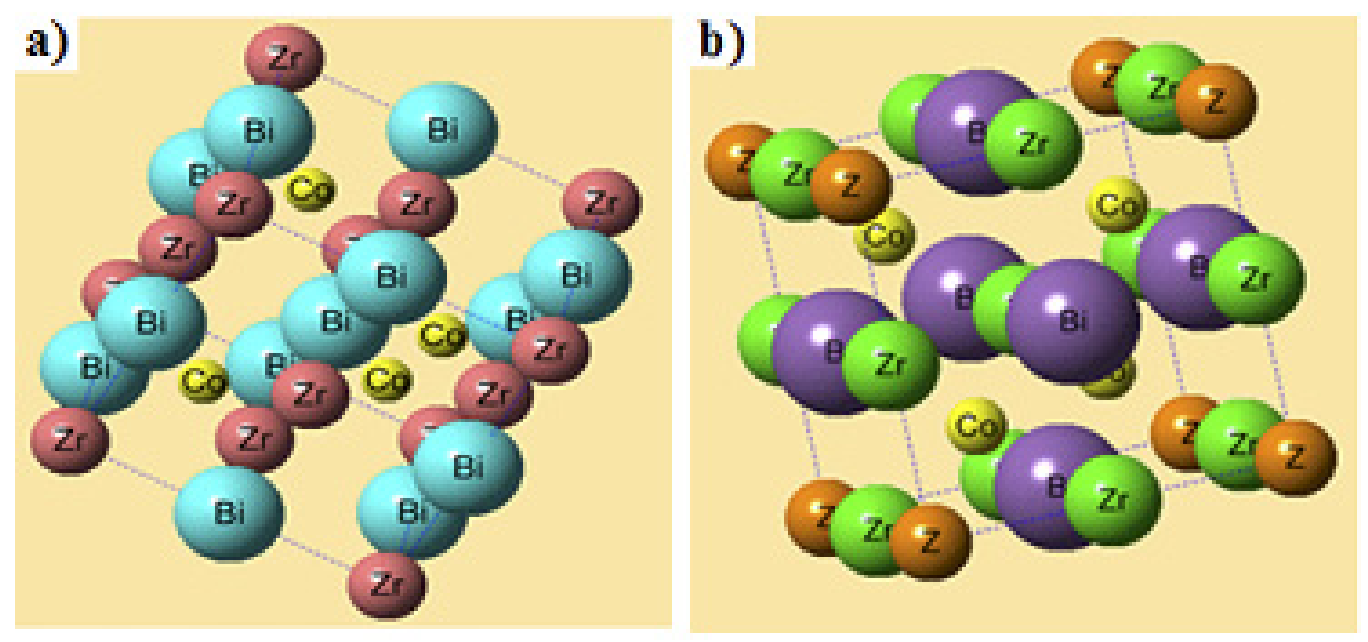

Figure 1. a) - Crystal structure of half-Heusler semiconductor $\mathrm{ZrCoBi}, \mathrm{b})$ - 12 atom simple cubic model of $\mathrm{ZrCoBi}_{0.75} \mathrm{Z}_{0.25}(\mathrm{Z}=\mathrm{P}, \mathrm{As}, \mathrm{Sb})$ structure.

The crystal structures of $\mathrm{ZrCoBi}_{0.75} \mathrm{Z}_{0.25}(\mathrm{Z}=\mathrm{P}, \mathrm{As}, \mathrm{Sb})$ are cubic with the space group of $\mathrm{P}-43 \mathrm{~m}$; the structure can be regarded as four interpenetrating fcc sublattices (Fig. 1b). The calculated structural properties such as lattice constants a, bulk modulus B, first derivatives B' and equilibrium energies Emin are recapitulated in Table 1.

Calculated lattice constant ao $\left(\mathrm{A}^{\circ}\right)$, bulk modulus $\mathrm{B}(\mathrm{GPa})$, derivative of the bulk modulus, $\mathrm{B}^{\prime}(\mathrm{GPa})$,

Table 1. minimum total energy per unit cell $\mathrm{E}_{\min }(\mathrm{Ry})$ and Gap energy $(\mathrm{eV})$

\begin{tabular}{|c|c|c|c|c|c|c|}
\hline Compounds & Space group & $\mathbf{A}(\mathbf{\AA})$ & B (GPa) & B' & Emin (Ry) & Gap (eV) \\
\hline Undoped $-\mathrm{ZrCoBi}$ & $216 \mathrm{~F}-43 \mathrm{~m}$ & 6.23 & 120.31 & 4.94 & -53148.552763 & 0.990 \\
\hline \multirow{2}{*}{$215 \mathrm{P}-43 \mathrm{~m}$} & 6.12 & 131.34 & 5.23 & -170115.352819 & 1.018 \\
\cline { 4 - 8 } & & 6.14 & 128.07 & 5.10 & -173953.361417 & 1.008 \\
\cline { 4 - 8 } $\mathrm{ZrCoBi}_{0.75} \mathrm{As}_{0.25}$ & 6.19 & 124.95 & 4.95 & -182398.455731 & 0.996 \\
\hline $\mathrm{ZrCoBi}_{0.75} \mathrm{Sb}_{0.25}$ & & &
\end{tabular}

The lattice constants for $\mathrm{ZrCoBi}_{0.75} \mathrm{P}_{0.25}, \mathrm{ZrCoBi}_{0.75} \mathrm{As}_{0.25}, \mathrm{ZrCoBi}_{0.75} \mathrm{Sb}_{0.25}$, show increase from $\mathrm{P}$ to $\mathrm{Sb}$ dopant. The three doping elements are electronegative and their atomic radii in increasing order is $\mathrm{P}, \mathrm{As}$ and $\mathrm{Sb}$. Fig. 2(a-d) show the calculated electronic band structure with high symmetric Brillouin zone W-L- $\Gamma-\mathrm{X}-\mathrm{W}-\mathrm{K}$ for undoped $\mathrm{ZrCoBi}$ and $\mathrm{ZrCoBi}_{0.75} \mathrm{Z}_{0.25}(\mathrm{Z}=\mathrm{P}$, As, Sb) Half-Heusler using the GGA approach. For the pristine case, the Fermi level lies inside the forbidden gap and the valance band maxima (VBM) and conduction band minima (CBM) occur at the $\mathrm{L}$ and $\mathrm{X}$ points, thus generating an indirect band gap of about $0.99 \mathrm{eV}$, which confirms the semiconducting nature of compound. The introduction of sp elements $(\mathrm{P}, \mathrm{As}, \mathrm{Sb})$ ions into $\mathrm{ZrCoBi}$ shifts the bottom point of the conduction band towards a higher energy than the undoped $\mathrm{ZrCoBi}$, thus increasing the band gap. The values to $0.996 \mathrm{eV}, 1.008 \mathrm{eV}$ and $1.018 \mathrm{eV}$ are obtained for $\mathrm{ZrCoBi}_{0.75} \mathrm{Sb}_{0.25}, \mathrm{ZrCoBi}_{0.75} \mathrm{As}_{0.25}$ and $\mathrm{ZrCoBi}_{0.75} \mathrm{P}_{0.25}$ respectively. The $\mathrm{VBM}$ and the $\mathrm{CBM}$ are located at the $\mathrm{L}$ and $\Gamma$ points, which indicates the change in momentum of the electrons during their transitions from VBM to CBM. Consequently, all the $\mathrm{ZrCoBi}_{0.75} \mathrm{Z}_{0.25}(\mathrm{Z}=\mathrm{P}, \mathrm{As}$, Sb) compounds are indirect band gap semiconductors. In order to study the positioning of the orbital's in the electronic band structure as well as the electrons involving in the shaping of the band gap, the total anacd partial density of states (TDOS/PDOSs) of pure and sp element (P, As, and Sb) doped $\mathrm{ZrCoBi}$ are investigated between -4 and $4 \mathrm{eV}$ Fig. 3(a-d). The dashed line displays the Fermi energy level (EF). We can see that the 
top of the VB is mainly determined by the hybridization of $\mathrm{d}-\mathrm{Zr}$, d-Co, $\mathrm{P}-\mathrm{Bi}$ and $\mathrm{p}-\mathrm{P}$ states, whereas the bottom of the $\mathrm{CB}$ is formed primarily by the d-states of $\mathrm{Co}$ and $\mathrm{Zr}$. From [- 4 to $-2 \mathrm{eV}]$, the anion d-Zr, d-Co, P-Bi and p-P states depict the lowest bands, these states are separated the main valence state (d-Co) by a small gap. The (PDOS) in this energy range is more pronounced for P-doped $\mathrm{ZrCoBi}$ than for As-doped $\mathrm{ZrCoBi}$ or Sb-doped $\mathrm{ZrCoBi}$. The density of states near the Fermi level for the $\mathrm{ZrCoBi}_{0.75} \mathrm{Z}_{0.25}(\mathrm{Z}=\mathrm{P}, \mathrm{As}, \mathrm{Sb}) \mathrm{HH}$, can be attributed to d-d orbitals hybridization between transition metals $(\mathrm{Zr} / \mathrm{Co})$. The p-orbitals of the $\mathrm{Z}$ atom contribute only slightly to the electronic properties. The offset of the valence bands toward the low energies is more larger for $\mathrm{ZrCoBi}_{0.75} \mathrm{Z}_{0.25}(\mathrm{Z}=\mathrm{P}$, As, Sb) than that for undoped-ZrCoBi, while the conduction bands remain almost in the same energy range (Fig. 3a). We observe that with increasing in atomic number of dopant element a shift of the main peak (d-Co) towards higher energies occurs $[\mathrm{P}(-1.22 \mathrm{eV}) / \mathrm{As}(-1.08 \mathrm{eV}) /$ $\mathrm{Sb}(-1.04 \mathrm{eV})]$.
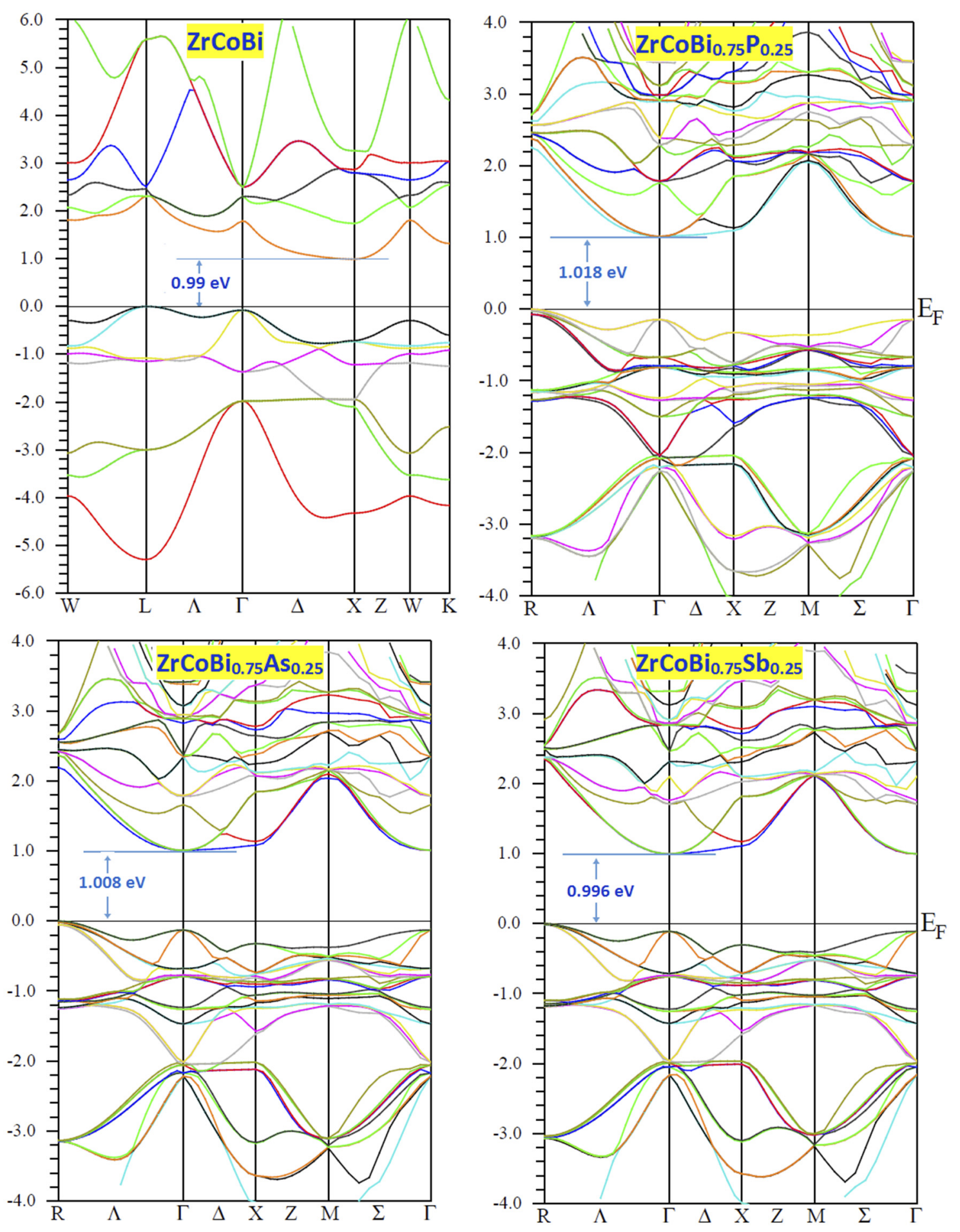

Figure 2. Band structure for a) undoped $\mathrm{ZrCoBi}$, b) $\mathrm{ZrCoBi}_{0.25} \mathrm{P}_{0.25}$, c) $\mathrm{ZrCoBi}_{0.25} \mathrm{As}_{0.25}$ and d) $\mathrm{ZrCoBi}_{0.25} \mathrm{Sb}_{0.25}$. 

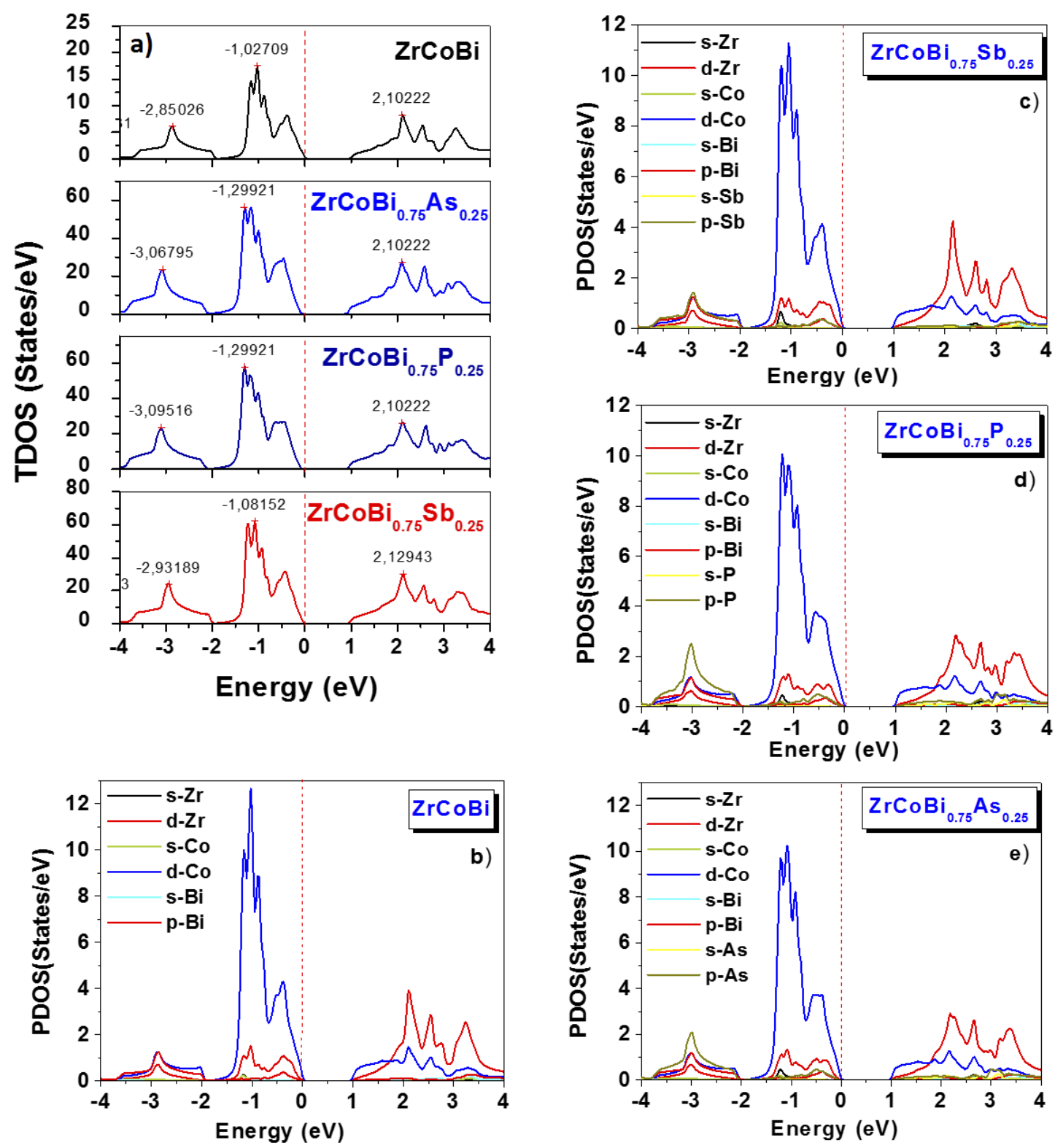

Figure 3. a) - Total density of states (TDOS), b-d) - Partial densities of states (PDOS)

\section{Thermoelectric properties}

The appropriate choice of the doping as well as its concentration remain among the principal factors which maximize the ZT of semiconductors and which make them suitable for the thermoelectric applications. The transport properties will be computed with BoltzTraP code under a constant relaxation time approximation of the charge carriers. The main thermoelectric parameters, such as Seebeck coefficient $(S)$, electrical conductivity $(\sigma / \tau)$, thermal conductivity $(\kappa / \tau)$ and figure of merit (ZT) will be investigated as function of temperature [25-26]. The temperature reliance of $\mathrm{S}$ is shown in Fig. 4c. It is observed that beyond temperature of $400 \mathrm{~K}$, the Seebeck coefficient (S) decrease steadily with the increase of temperature for the $\mathrm{ZrCoBi}_{0.75} \mathrm{Z}_{0.25}(\mathrm{Z}=\mathrm{P}, \mathrm{As}, \mathrm{Sb}) \mathrm{HH}$. This limitation of $\mathrm{S}$ at high temperature can be attributed to the bipolar effects which occur for wide-bandgap semiconductors and which result in an increase of thermal conductivity [27]. Among the three doped compounds, the P-doped $\mathrm{ZrCoBi}$ exhibit the large Seebeck coefficient of 289 $\mu \mathrm{V} / \mathrm{K}$ between 300 to $400 \mathrm{~K}$, this obtained value of $\mathrm{S}$ has been improved by $22 \%$ than the undoped $\mathrm{ZrCoBi}$. With the increased of the atomic mass of the doping element, a diminution of $\mathrm{S}$ was observed. The positive values of Seebeck coefficient confirm that the $\mathrm{ZrCoBi}_{0.75} \mathrm{Z}_{0.25}(\mathrm{Z}=\mathrm{P}, \mathrm{As}, \mathrm{Sb})$ are p-type semiconductors. The obtained values of $\mathrm{S}$ around room temperature are larger to those reported by several doped and undoped $\mathrm{HH}$ compounds such $\mathrm{TiCoSn}_{x} \mathrm{Sb}_{1-x}[28]$, $\mathrm{FeV}_{1-\mathrm{x}} \mathrm{Hf}_{\mathrm{x}} \mathrm{Sb}$ [29], PdZrGe [30] ScRhTe [31]. Our compounds are good thermoelectric materials (TM), because according to J.W. Sharp [32], the best TM are highly doped semiconductors with a Seebeck coefficient located in the domain $150-250 \mu \mathrm{V} \mathrm{K}^{-1}$. The ability of the $\mathrm{ZrCoBi}_{0.75} \mathrm{Z}_{0.25}(\mathrm{Z}=\mathrm{P}, \mathrm{As}, \mathrm{Sb}) \mathrm{HH}$ to transfer heat is investigated in this section by the computation of its thermal conductivity $(\kappa / \tau)$. Fig. $4 \mathrm{~b}$ shows temperature dependence of $\kappa / \tau$ of doped and undoped $\mathrm{ZrCoBi}$. 

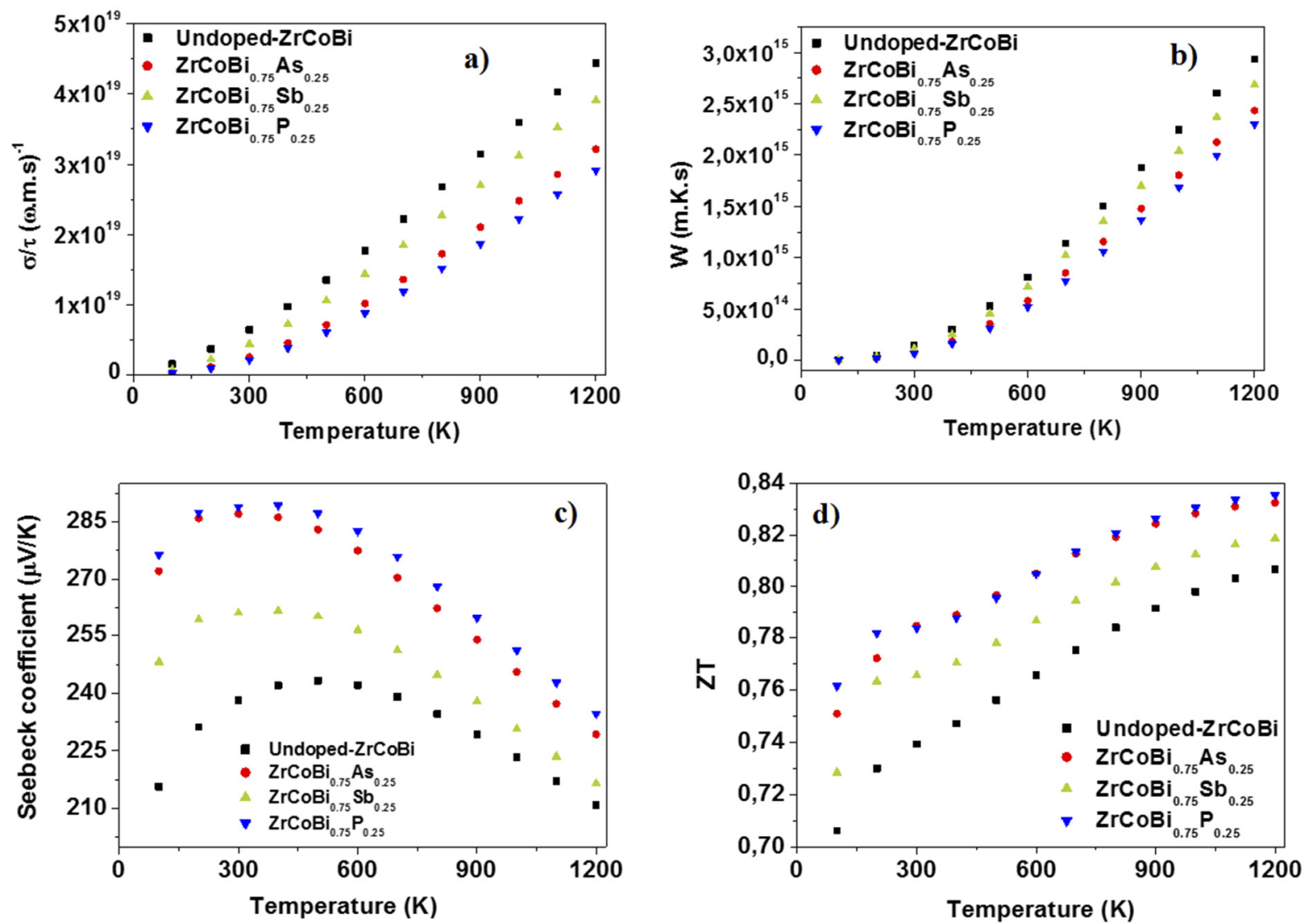

Figure 4. Thermoelectric properties versus temperature

a) Electrical conductivity b) Thermal conductivity c) Seebeck coefficient and d) figure of merit

We can see that doping reliance of the $\kappa / \tau$ showed a decreasing value comparatively to the undoped $\mathrm{ZrCoBi}$, which is advantageous for improving the ZT value. After $400 \mathrm{~K}$, the $\kappa / \tau$, which is directly allied with electrical conductivity, augments with temperature in a very linear trend and the slope of the $\kappa / \tau$ curves increases with increasing the $Z$-atomic number. The $\kappa / \tau$ which is also influenced by the evolution of charge-carrier concentration, show at $300 \mathrm{~K}$ a value of about 5.90.10 ${ }^{13} \mathrm{~W} / \mathrm{m}$.K.s which is comparable with that of $\mathrm{Pb}_{7} \mathrm{Bi}_{4} \mathrm{Se}_{13}$ [33], CdSe, CdTe [34]. In comparison with undoped $\mathrm{ZrCoBi}$, a reduction of nearly $23 \%$ in the $\kappa / \tau$ was obtained at $1200 \mathrm{~K}$ by the substitution of the Bismuth site by the Phosphor. Around the ambient temperature, the $\kappa / \tau$ is weak then it sudden increases with the increasing in temperature this is due to electron-phonon scattering [35]. With an increase from $5.91 .10^{12} \mathrm{mKs}$ at $100 \mathrm{~K}$ to $2.69 .10^{15} \mathrm{mKs}$ at $1200 \mathrm{~K}$, and with value of $6.50 .10^{13} \mathrm{~W} / \mathrm{mKs}$ at room temperature $(300 \mathrm{~K})$, the $\mathrm{ZrCoBi}_{0.75} \mathrm{Sb}_{0.25}$ constitutes a good thermal conductor. The effectiveness of thermoelectric devices requires a sufficiently high electrical conductivity $(\sigma / \tau)$ to achieve a high figure of merit (ZT). Fig. 4(a) shows the temperature dependence of $\sigma / \tau$ for the $\mathrm{ZrCoBi}_{0.75} \mathrm{Z}_{0.25}$ compounds. The $\sigma / \tau$ displays exponential growth with increasing temperature due to the increase in the number of carriers. The $\mathrm{ZrCoBi}_{0.75} \mathrm{Sb}_{0.25}$ exhibits the highest value of $\sigma / \tau$ comparatively to $\mathrm{ZrCoBi}_{0.75} \mathrm{As}_{0.25}$ and $\mathrm{ZrCoBi}_{0.75} \mathrm{P}_{0.25}$, because the antimony shows the greater atomic weight to that of arsenic and phosphour. The increase in atomic weight augments the number of electronic layer and nucleus grip on the valence electrons then becomes weak. Several electrons are pushed toward the conduction band leading to improve the $\sigma / \tau$ values [23]. At room temperature, the $\sigma / \tau$ is of $4.41 .10^{18}, 2.52 .10^{18}$

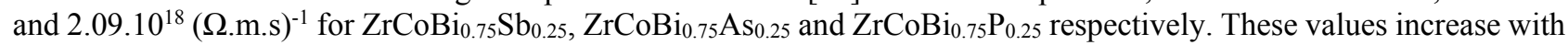
the temperature and reaches the maximum of $3.91 .10^{19}, 3.21 .10^{19}$ and $2.91 .10^{19}(\Omega . \mathrm{m} . \mathrm{s})^{-1}$ at $1200 \mathrm{~K}$. The increasing trend of $\sigma / \tau$ displayed for doped $\mathrm{ZrCoBi}$ and undoped $\mathrm{ZrCoBi}$ is in agreement with previous studies done on the semiconductors compounds [36-37]. The calculated values of figure of merit versus temperature are presented in Fig. 4d. There is a continuous increase in $\mathrm{ZT}$ with increasing temperature. The undoped $\mathrm{ZrCoBi}$ has the lowest $\mathrm{ZT}$ value at all temperatures and by substituting bismuth atom by one of the sp elements (P, As, Sb), an increase of the ZT was observed. A maximum $\mathrm{ZT}=0.85$ was obtained at $1200 \mathrm{~K}$ with a $25 \% \mathrm{P}$-substitution at the Bi-site. At low temperature $(100 \mathrm{~K})$, the deviation of $\mathrm{ZT}$ between the doped and undoped structures is much more marked. The high values of the Seebeck coefficient as well as the electrical conductivity of $\mathrm{ZrCoBi}_{1-\mathrm{x}} \mathrm{Z}_{\mathrm{x}}$ alloys did not translate into high values of $\mathrm{ZT}$ because of rather high thermal conductivity. The difference in mass and radius between $\mathrm{Bi}$ and $\mathrm{Z}$ are responsible for the high thermal conductivity. However, others adjustment remains necessary for more improvement let's quote the concentration of the dopant element which should be optimized to decrease more the density of transport electrons also the use of second substituting atom (co-doping) with larger mass can reduce the thermal conductivity [38]. Despite that, the figure of merit and Seebeck 
coefficients values obtained and which have been widely improved by doping we can conclude that ours doped compounds have the capacity to transform waste heat into electric energy and may be also used in various thermoelectrically devices.

\section{CONCLUSION}

By using the first-principle density-functional theory within the supercell approach, we have studied the $\mathrm{ZrCoBi}_{0.75} \mathrm{Z}_{0.25}(\mathrm{Z}=\mathrm{P}, \mathrm{As}, \mathrm{Sb})$ half-Heusler, a particular emphasis was placed on the thermoelectric properties. The calculated band structures reveal that the doped and undoped-ZrCoBi are indirect band gap semiconductors. The substitution of the Bi site by $\mathrm{P}, \mathrm{As}$ and $\mathrm{Sb}$ is found effective in decreasing thermal conductivity and increasing the Seebeck coefficient and figure of merit value. Comparatively to undoped- $\mathrm{ZrCoBi}$, the $\mathrm{ZrCoBi}_{0.75} \mathrm{P}_{0.25}$ show improvements of $22 \%$ and $54 \%$ of its Seebeck coefficient and thermal conductivity respectively. An enhancement of ZT values of $7.8 \%$ and $6.1 \%$ have been observed at $100 \mathrm{~K}$ and $300 \mathrm{~K}$ between the undoped- $\mathrm{ZrCoBi}$ and $\mathrm{P}$-doped $\mathrm{ZrCoBi}$ half-Heusler. In order to further boost the performance of these alloys, future work will focus on single doping with very low dopant concentration as well as on co-doping.

\section{ORCID IDs}

Djelti Radouan, https://orcid.org/0000-0002-0762-5818; (D)Besbes Anissa, https://orcid.org/0000-0002-2853-1909;

(D)Bestani Benaouda, https://orcid.org/0000-0002-1104-0900

\section{REFERENCES}

[1] T. Zhu, C. Fu, H. Xie, Y. Liu, and X. Zhao, Adv. Energy Mater. 5, 1-13 (2015), https://doi.org/10.1002/aenm.201500588.

[2] I.P. Ezekiel, and T. Moyo, Journal of Alloys and Compounds, 749, 672-680 (2018), https://doi.org/10.1016/j.jallcom.2018.03.349.

[3] A. Karati, S. Mukherjee, R.C. Mallik, R, Shabadi, B.S. Murty, and U.V. Varadaraju, Materialia, 7, 100410 (2019), https://doi.org/10.1016/j.mtla.2019.100410.

[4] A. Bandyopadhyaya, S.K. Neogia, A. Paul, C. Meneghini, I. Dasgupta, and S. Ray, Journal of Alloys and Compounds, 764, 656664 (2018), https://doi.org/10.1016/j.jallcom.2018.06.065.

[5] T.C. Chibueze, A.T. Raji, and C.M.I. Okoye, Chemical Physics, 530, 110635 (2020), https://doi.org/10.1016/j.chemphys.2019.110635.

[6] Z. Wendan, L. Yong, L. Yunsheng, W. Jiahua, H. Zhiling, and S. Xiaohong, Chemical Physics Letters, 741, 137055 (2020), https://doi.org/10.1016/j.cplett.2019.137055.

[7] J.Shen, L. Fan, C. Hu, T. Zhu, J. Xin, T. Fu, D. Zhao, and X. Zhao, Materials Today Physics, 8, 62-70 (2019), https://doi.org/10.1016/j.mtphys.2019.01.004.

[8] A. Bhardwaj, and D.K. Misra, J. Mater. Chem. A, 2, 20980-20989 (2014), https://doi.org/10.1039/C4TA04661G.

[9] E. Lkhagvasuren, S. Ouardi, G.H. Fecher, G. Auffermann, G. Kreiner, W. Schnelle, and C. Felser, Optimized thermoelectric performance of the $n$-type half-Heusler material TiNiSn by substitution and addition of Mn, AIP Advances, 7, 045010 (2017), https://doi.org/10.1063/1.4979816.

[10] S. Chen, and Z. Ren, Mater. Today, 16(10), 387-395 (2013), https://doi.org/10.1016/j.mattod.2013.09.015.

[11] S.J. Poon, D. Wu, S. Zhu, W. Xie, T.M. Tritt, P. Thomas, and R. Venkatasubramanian, J. Mater. Res. 26, 2795-2802 (2011), https://doi.org/10.1557/jmr.2011.329.

[12] J. Shen, C. Fu, Y. Liu, X. Zhao, and T. Zhu, Energy Storage Materials, 10, 69-74 (2018), https://doi.org/10.1016/j.ensm.2017.07.014.

[13] C.-C. Hsu, and H.-K. Ma, Materials Science and Engineering B, 198, 80-85 (2015), https://doi.org/10.1016/j.mseb.2015.03.015.

[14] Y. Lei, C. Cheng, Y. Li, R, Wan, and M. Wang, Ceramics International, 43, 9343-9347 (2017), https://doi.org/10.1016/j.ceramint.2017.04.100.

[15] R. Akram, Y. Yan, D. Yang, X. She, G. Zheng, X. Su, and X. Tang, Intermetallics, 74, 1-7 (2016), https://doi.org/10.1016/j.intermet.2016.04.004.

[16] R. Akram, Q. Zhang, D. Yang, Y. Zheng, Y. Yan, X. Su, and X. Tang, Journal of electronic materials, 44(10), 3563-3570 (2015), https://doi.org/10.1007/s11664-015-3882-6.

[17] O.K. Andersen, Phys. Rev. B, 42, 3060 (1975), https://doi.org/10.1103/PhysRevB.12.3060.

[18] D.J. Singh, Planes Waves, Pseudo-potentials and the LAPW Method, (Kluwer Academic Publishers, Boston, 1994).

[19] P. Hohenberg, and W. Kohn, Phys. Rev. B, 136, 864-871 (1964), https://doi.org/10.1103/PhysRev.136.B864.

[20] P. Blaha, K. Schwarz, G.K.H. Madsen, D. Kvasnicka, and J. Luitz, WIEN2k, An Augmented Plane Wave Plus Local Orbitals Program for Calculating Crystal Properties, (Vienna University of Technology, Austria, 2001), pp. 269, http://www.wien2k.at/reg_user/textbooks/usersguide.pdf.

[21] J.P. Perdew, K. Burke, and M. Ernzerhof, Phys. Rev. Lett. 77, 3865 (1996) 68, https://doi.org/10.1103/PhysRevLett.77.3865.

[22] G. Surucu, M. Isik, A. Candan, X. Wang, and H.H. Gullu, Physica B, 587, 412146 (2020), https://doi.org/10.1016/j.physb.2020.412146.

[23] G.K.H. Madsen, D.J. Singh, Comput. Phys. Commun. 175, 67-71 (2006), https://doi.org/10.1016/j.cpc.2006.03.007.

[24] Crystalmaker software Ltd, Begbroke, Oxfordshire OX5 1PF, UK, http://www.crystalmaker.com.

[25] R. Hasan, and S.-C. Ur, Transactions on Electrical and Electronic Materials, 19(2), 106-111 (2018), https://doi.org/10.1007/s42341-018-0024-x.

[26] T. Wu, W. Jiang, X. Li, S. Bai, S. Liufu, and L. Chen, Journal of Alloys and Compounds, 467(1-2), 590-594 (2009), https://doi.org/10.1016/j.jallcom.2007.12.055.

[27] G.J. Snyder, and E.S. Toberer, Nat. Mater. 7(2), 105-114 (2008), https://doi.org/10.1038/nmat2090.

[28] T. Sekimoto, K. Kurosaki, H. Muta, and S. Yamanaka, Journal of Alloys and Compounds, 407, 326-329 (2006), https://doi.org/10.1016/j.jallcom.2005.06.036.

[29] A. El-Khouly, A. Novitskii, A.M. Adam, A. Sedegov, A. Kalugina, D. Pankratova, D. Karpenkov, and V. Khovaylo, Journal of Alloys and Compounds, 820, 153413 (2020), https://doi.org/10.1016/j.jallcom.2019.153413. 
[30] B. Anissa, D. Radouan, B. Benaouda, and A. Omar, Chinese Journal of Physics, 56, 2926-2936 (2018), https://doi.org/10.1016/j.cjph.2018.09.027.

[31] K. Kaur, and J. Kaur, Journal of Alloys and Compounds, 715, 297-303 (2017), https://doi.org/10.1016/j.jallcom.2017.05.005.

[32] J.W. Sharp, in: Encyclopedia of Condensed Matter Physics, edited by F. Bassani, G.L. Liedl, and P. Wyder, (Academic Press, Cambridge, MA, 2005), pp. 173-180, https://doi.org/10.1016/B0-12-369401-9/00507-6.

[33] S. Azam, S. Goumri-Said, S.A. Khan, H. Ozisik, E. Deligoz, M.B. Kanoun, and W. Khan, Materialia, 10, 100658 (2020), https://doi.org/10.1016/j.mtla.2020.100658.

[34] M. Naseri, D.M. Hoat, J.F. Rivas-Silva, and G.H. Cocoletz, Optik, 210, 164567 (2020), https://doi.org/10.1016/j.ijleo.2020.164567.

[35] V.F. Gantmakher, Reports on Progress in Physics, 37(3), 317 (1974), https://doi.org/10.1088/0034-4885/37/3/001.

[36] A.A. Khan, I. Khan, I. Ahmad, and Z. Ali, Materials Science in Semiconductor Processing, 48, 85-94 (2016), https://doi.org/10.1016/j.mssp.2016.03.012.

[37] S. Azam, M. Umer, U. Saeed, W. Khan, M. Irfan, Z. Abbas, and I.V. Kityk, Journal of Molecular Graphics and Modelling, 94, 107484 (2020), https://doi.org/10.1016/j.jmgm.2019.107484.

[38] M.A.A. Mohamed, E.M.M. Ibrahim, N.P. Rodriguez, S. Hampel, B. Büchner, G. Schierning, K. Nielsch, and R. He, Acta Materialia, 196, 669-676 (2020), https://doi.org/10.1016/j.actamat.2020.07.028.

\section{ДОСЛІДЖЕНЯ ЕЛЕКТРОННИХ ТЕРМОЕЛЕКТРИЧНИХ ВЛАСТИВОСТЕЙ ZrCoВi ЛЕГОВАНОГО (P, Аs, Sb)} Джелті Радуан ${ }^{a}$ Бесбес Аніса, Бестані Бенауда ${ }^{b}$

а Лабораторія технологій та властивостей твердих речовин, Університет Мостаганему (UМАВ) - Алжир

bЛабораторія SEA2M, Університет Мостаганему (UMAB) - Алжир

Протягом останнього десятиріччя напів-Гайслерові сполуки (НH) займають важливе місце в галузі досліджень фізики конденсованої речовини. Численність заміщень перехідних елементів на кристалографічних ділянках X, Y та (III-V) елементів на Z-ділянках надає сплавам напів-Гайслера (HН) безліч надзвичайних властивостей. У цьому дослідженні ми вивчали структурні, електронні та термоелектричні властивості $\mathrm{ZrCoBi}_{0,75} \mathrm{Z}_{0,25}(\mathrm{Z}=\mathrm{P}, \mathrm{As}, \mathrm{Sb})$, використовуючи теорію функціоналу щільності (DFT). Розрахунки проводились паралельно 3 використанням метода повного потенціалу лінеаризованої розширеної плоскої хвилі (FP-LAPW), який був реалізований в коді WIEN2k. Термоелектричні властивості були прогнозовані за допомогою напівкласичної теорії транспорту Больцмана, яка була реалізована в коді Больцтрапа. Отримані результати для зонної структури та щільностей станів підтверджують напівпровідникову (SC) природу трьох сполук із непрямим проміжком енергетичної зони, який становить близько 1 еВ. Основні термоелектричні параметри, такі як коефіцієнт Зеебека, теплопровідність, електропровідність та порівняльний показник якості, були оцінені для температур від нуля до $1200 К$. Позитивні значення коефіцієнта Зеебека (S) підтверджують, що $\mathrm{ZrCoBi}_{0.75} \mathrm{Z}_{0.25}(\mathrm{x}=0$ та 0,25) є SC типу р. При температурі навколишнього середовища $\mathrm{ZrCoBi} 0.75 \mathrm{P}_{0,25}$ демонструє значну величину $(\mathrm{S})$, яка складає $289 \mu \mathrm{V} / \mathrm{K}$, що означає покращення на $22 \%$ порівняно з нелегованим $\mathrm{ZrCoBi}$, а також демонструє зменшення теплопровідності на $54 \%(\mathrm{k} / \tau)$. Нелегований $\mathrm{ZrCoBi} \mathrm{має}$ найнижче значення ZT при будь-яких температурах, i, при заміщенні атома вісмуту одним із sp-елементів (P, As, Sb), одночасне покращення $\mathrm{k} / \tau$ та $\mathrm{S}$ призводить до досягнення максимальних значень порівняльного показника якості $(\mathrm{ZT}) \sim 0,84$, отриманого при 1200 К для трьох легованих сполук.

КЛЮЧОВІ СЛОВА: першооснова, GGA, легований напівпровідник, коефіцієнт Зеебека, порівняльний показник якості 